\title{
Establishment and Functionality of Diverse Endophytic Bacteria from Different Hosts in Chickpea and Wheat Microbiome
}

\author{
Rupa Giri and Surjit Singh Dudeja* \\ Department of Microbiology, Chaudhary Charan Singh Haryana Agricultural University \\ Hisar, 125004, India \\ *Corresponding author
}

\section{Keywords}

Chickpea, Wheat,

Host specificity,

Nodulation,

Establishment,

endophytes, $16 \mathrm{~S}$

rDNA

Article Info

Accepted:

17 March 2019

Available Online:

10 April 2019

\section{A B S T R A C T}

Functionality associated with the plants play an important role in the health and growth of plants. Eleven endophytic bacterial isolates from different hosts were identified and were used for studying their functionality. Different endophytes identified by partial sequencing of 16S rDNA were: Bacillus licheniformis strain CRE1; B. subtilis, strain CNE215; $B$. subtilis strain PRE8; Bacillus sp. strain PNE17; B. cereus, strain PNE92; B. subtilis, strain LRE3; Bacillus sp. strain LRE7; Bacillus sp. strain WRE4; B. flexus strain WRE20; $B$. subtilis, strain ORE35 and Brevibacterium iodinum strain ORE27. All endophytes produced IAA, solubilized P, few produced siderophores, showed cellulose hydrolysis and exoglucanase activity. Majority of the endophytic did not show any inhibitory activity against Fusarium oxysporum. Establishment of different endophytic bacteria in chickpea and wheat plants at 60d of growth showed that three strains CNE215, PNE17 and ORE27 were detected in the chickpea roots with maximum $2.05 \log \mathrm{CFU}$ plant root $^{-1}$ of strain PNE17. In case of wheat roots at 60d of growth another three strains LRE3, LRE7 and ORE27 were detected with $2.17 \log$ CFU plant root $^{-1}$ of strain LRE3. Total shoot nitrogen and P contents increased significantly after co inoculation with strain CNE215 in chickpea, and with ORE27 in wheat.

\section{Introduction}

Bacterial endophytes offer several benefits to the host plant, particularly growth pro-motion and protection from pathogens. Bacterial endophytes communicate and interact with the plant more efficiently as compared to rhizospheric bacteria (Ali et al., 2012; Coutinho et al., 2015, Santoyo et al., 2016). However both types act as plant growth promoting bacteria (PGPB); rhizospheric bacteria, that are typically found around the roots of plants; and endophytic bacteria that are found within the various tissues of the plant itself (e.g. roots, nodules, stems, leaves, seeds, and fruits) (Ryan et al., 2008; Lacava and Azevedo, 2013; Tshikhudo et al., 2019).

To colonize the internal plant tissues, it has been proposed that in bacterial endophytes no definitive group of genes has been identified which is responsible for the endophytic life style. However, a list of genes with possible roles in endophytic behavior was recently 
identified by Ali et al., (2014a, b) by comparing the complete genomes of different Proteobacterial endophytes. The mechanisms employed by bacteria to promote plant growth are now better understood (Gamalero and Glick, 2011; Glick, 2012; Tshikhudo et al., 2019). PGPB and particularly endophytic bacteria promote the growth of plants by possessing multiple beneficial traits like production of phytohormones, auxins, IAA, Gibberellin, together with cytokinin and ethylene (Dudeja 2012; Etesami and Maheshwari 2018). Vitamins, thiamine, biotin, riboflavin and niacin, siderophores, and solubilization of phosphorous by acidification, secretion of organic acids or protons and chelation resulting in enhanced nutrient acquisition and suppressing stressinduced ethylene synthesis. Bacterial endophytes protect the plants against disease and abiotic stresses of salinity, draught and heavy metals. $\mathrm{N}$-acyl-homoserine lactones act as the signaling molecules. Biological nitrogen fixation by endophytic bacteria in different plant parts is another important functional trait for enhancing plant growth (Kirchhof et al., 1997; Stoltzfus et al., 1997; Reinhold-Hurek and Hurek, 2011; Jha et al., 2013; Berendsen et al., 2012).

Plant-bacterial interactions reveals that plants are able to shape their rhizosphere and endophytic microbiome (Berendsen et al., 2012) and recruit bacteria that contain specific adaptive characteristic to the existing environmental conditions in that niche. These bacterial endophytes may perform similar or different functions in different plants and different plant tissues. Host-endophytic bacterial interactions are less well understood. Particularly, very few studies from Indian subcontinent are reported from northern India where soil temperature range is -2 to $47^{\circ} \mathrm{C}$ (Dudeja and Giri 2014; Saini et al., 2015b). Therefore, the present investigation was planned to study the establishment and functionality of different endophytes obtained from different tissues (root and nodules) and hosts (legumes and non-legumes) in Chickpea legume and wheat a non-legumes. To address the interactions and host specificity (if any) between host and endophytic bacteria leading to successful colonization and establishment existence as endophyte and benefits being incurred by the host and thereby enhancing the crop productivity.

\section{Materials and Methods}

\section{Selection of diverse bacterial endophytic isolates from roots and nodules}

About 200 endophytic bacteria isolated in the previous studies from nodules of chickpea (Cicer arietinum), field pea (Pisum sativum) and roots of chickpea, field pea, Lucerne (Medicago sativa), wheat (Triticum aestivum) and oat (Avena sativa) were used to select efficient isolates from all the sources as reported earlier (Kumar et al., 2013; Narula et al., 2013a, b). Out of these, 11 endophytic bacterial isolates, CRE1, CNE215, PRE8, PNE17, PNE92, LRE3, LRE7, WRE4, WRE20, ORE27, and ORE35 were selected for further studies (Giri and Dudeja 2013a, b). Selected endophytes included one from the chickpea nodules (CNE), two from the field pea nodules (PNE), one each from roots of chickpea (CRE) and field pea (PRE) and two each from the roots of wheat (WRE), oat (ORE) and lucerne (LRE).

\section{Identification of selected endophytic bacteria}

Two endophytes were identified earlier and genomic DNA of remaining 9 bacterial endophytes was extracted using CTAB method (Saini et al., 2015a). Total genomic DNA was isolated by standard phenolchloroform extraction method (Sambrook and Russell, 2001). Finally the DNA was 
quantified and stored at $-20^{\circ} \mathrm{C}$. Amplification of $16 \mathrm{~S}$ rDNA of root and nodule endophytes was carried out using primers fD1and rD1 (Ausubel 2001). PCR amplification was carried out by modifying the protocol as described earlier (Wadhwa et al 2011). The conditions for PCR included initial denaturation at $94^{\circ} \mathrm{C}$ for $3 \mathrm{~min}$; denaturation at $94^{\circ} \mathrm{C}$ for $45 \mathrm{~s}$; annealing at $50^{\circ} \mathrm{C}$ for $40 \mathrm{~s}$; extension at $72^{\circ} \mathrm{C}$ for $1 \mathrm{~min}$; and final extension at $72^{\circ} \mathrm{C}$ for $10 \mathrm{~min}$ with 40 repeating cycles. The amplified fragments were separated by electrophoresis and were stained with ethidium bromide $\left(1 \mathrm{mg} \mathrm{ml}^{-1}\right)$ and photographed under UV illumination with Gel Doc (DNR Bio-Imaging Systems). The partial sequence of $16 \mathrm{~S}$ rRNA gene of nine endophytic bacterial isolates obtained after sequencing (Merck Millipore DNA sequencing service, Bangalore, India) was compared with the sequences already submitted in the NCBI (National Center for Biotechnology Information) database using the BLASTN program (Altschul et al., 1997). Phylogenetic analysis was performed by the construction of phylogenetic tree using MEGA 4 software (Tamura et al., 2007), through neighbour joining method (Saitou and Nei, 1987).

\section{Screening of bacterial endophytes for PGP traits}

All the 11 selected bacterial endophytes were screened for the presence of different beneficial traits like IAA production; $\mathrm{P}$ solubilization; siderophore production; biocontrol activity against fungal pathogen (Fusarium spp.) and cellulolytic activity.

Bacterial endophytic isolates were tested for their ability to produce IAA. Cultures were inoculated in $30 \mathrm{~mL}$ LB broth supplemented with $100 \mu \mathrm{g} \mathrm{ml}^{-1}$ DL-tryptophan (Hartman et al., 1983) and were incubated at $28 \pm 2^{\circ} \mathrm{C}$ for $72 \mathrm{~h}$ and IAA in the culture supernatant was determined by adding Salkowski reagent (Glickmann and Dessaux 1995; Jangu and Sindhu 2011).

The log phase growing endophytic bacterial cultures were spotted on Pikovskaya's medium plates and incubated at $28 \pm 2^{\circ} \mathrm{C}$ for 5$7 \mathrm{~d}$. The colony growth and clearing zone diameter were measured after incubation. The solubilization efficiency (SE) was determined by $\mathrm{HD} / \mathrm{CD} \times$ Annule area $\times 100$, where, $\mathrm{CD}=$ colony diameter $(\mathrm{cm}), \mathrm{HD}=$ halo zone diameter $(\mathrm{cm})$. Annule area $\left(\mathrm{cm}^{2}\right)=\pi(\mathrm{R} 1+$ $\mathrm{R} 2)(\mathrm{R} 1-\mathrm{R} 2)$; Where, $\mathrm{R} 1=$ radius of clearing zone $(\mathrm{cm})$ and $\mathrm{R} 2=$ radius of colony growth (cm).

Further P solubilization activity in liquid was also assessed by growing endophytes in Pikovskaya's broth. After 10 days of growth contents were filtered and centrifuged to remove cells and debris and supernatants were used to assay the $\mathrm{P}$ solubilization activity (Jackson 1973).

Cellulase activity in term of FPase and CMCase activity was determined. For cellulase production, $100 \mathrm{~mL}$ of Mandels and Sternberg medium (Mandels, 1969) was inoculated with endophytic bacterial cultures. After growth at $28 \pm 2^{\circ} \mathrm{C}$, culture filtrate obtained by filtration was used for determining cellulase activity. Siderophore production using Chrome azurol S (CAS) agar plates (Schwyn and Neilands, 1987) was determined.

The interaction of endophytic bacterial isolates with Fusarium oxysporum was studied by the spot test method of Sindhu et al., (1999) on PDA medium plates. Spore suspension of the Fusarium oxysporum was spread over PDA medium plates followed by spotting of endophytic bacterial cultures. After incubation for $48 \mathrm{~h}$ at $28 \pm 2^{\circ} \mathrm{C}$ and growth inhibition of fungus was observed. 
Establishment and functionality of different endophytes in chickpea and wheat

Root and nodule colonization of all the bacterial endophytes and their efficacy was assessed under pot culture conditions using chickpea and wheat as test hosts. Sandy soil was collected from dry land area of CCS Haryana Agricultural University research farm. The soil analysis showed that it was sandy soil of $\mathrm{pH} 8.6$; organic C $0.15 \mathrm{Kg} \mathrm{ha}^{-1}$; electrical conductivity $0.53 \mathrm{dSm}^{-1}$. phosphorus $6 \mathrm{Kg} \mathrm{ha}^{-1}$; potassium $293 \mathrm{Kg} \mathrm{ha}^{-1}$ with $126 \mathrm{Kg} \mathrm{ha}^{-1}$ as available N. Eight $\mathrm{kg}$ of soil was taken in earthern pots. Seeds of chickpea var. HC-5 and wheat var. WH-711 were surface sterilized by using $0.2 \%$ mercuric chloride and alcohol. Four replicates of each treatment were kept and in case of chickpea, uniform inoculation of Mesorhizobium sp. strain $\mathrm{CH} 1233$ was also done. All the seeds were inoculated with each bacterial endophytic isolate. Two controls were also kept, one absolute control without any treatment and one only with Mesorhizobium inoculation alone in chickpea, and three plants in each pot were maintained. Pots were irrigated on alternate day or as and when required. Chickpea and wheat plants were uprooted after 15, 30 and $60 \mathrm{~d}$ of plant growth and establishment of endophytes was observed in roots, whereas in chickpea in nodules at 60d. To determine the establishment of endophytic bacteria, presence of antibiotic markers in all the 11 endophytic bacteria was determined as detailed earlier (Giri and Dudeja, 2013a). Multiple antibiotic resistance markers in each isolate were identified. After surface sterilization of roots or nodules were streaked on respective multiple antibiotics plates and growth was observed. After $60 \mathrm{~d}$ of growth recovered plants were also used for root, nodule and shoot biomass, and $\mathrm{N}$ and $\mathrm{P}$ uptake in chickpea and wheat except nodule and nodule biomass. Total nitrogen and phosphorus contents in plant and soil were estimated by Kjeldahl's (Bremmer, 1960) and John's (1970) methods respectively.

\section{Results and Discussion}

Efficient endophytic bacteria selected based on earlier studies included one from chickpea nodules (CNE), two from the field pea nodules (PNE), one each from roots of chickpea (CRE) and field pea (PRE) and two each from the roots of wheat (WRE), oat (ORE) and lucerne (LRE). Two isolates identified earlier were Bacillus subtilis strain CNE215 and Bacillus licheniformis strain CRE1. DNA fragments of approx $1300 \mathrm{bp}$ amplified from the 16S rRNA gene of the remaining 9 bacterial endophytes was got sequenced after purification from Merck Millipore DNA sequencing service, Bangalore, India. The sequences were aligned with NCBI database using BLAST programme. Most of the endophytes showed more than $98 \%$ similarity with Firmicutes, except one i.e. strain ORE27 which belonged to Actinobacteria i.e. Brevibacterium iodinum. Different endophytes identified from different sources were: Bacillus licheniformis strain CRE1 isolated from chickpea roots; $B$. subtilis, strain CNE215 isolated from chickpea nodules; B. subtilis strain PRE8 isolated from field pea roots; Bacillus $s p$. strain PNE17 and B. cereus, strain PNE92 isolated from field pea nodules; $B$. subtilis, strain LRE3 and Bacillus sp. strain LRE7 isolated from lucerne roots; Bacillus sp. strain WRE4 and B. flexus strain WRE20 isolated from wheat roots; $B$. subtilis, strain ORE35 and Brevibacterium iodinum strain ORE27 isolated from oat roots. A phylogenetic tree of all the identified endophytic bacteria was prepared using MEGA 4 programme (Fig. 1).

All the 11 endophytic bacterial strains (CRE1, CNE215, PRE8, PNE17, PNE92, LRE3, LRE7, WRE4, WRE20, ORE27, and ORE35) 
produced IAA ranging from 1.33 to $35.6 \mu \mathrm{g}$ $\mathrm{ml}^{-1}$ (Fig. 2a). Root endophyte strain ORE27 showed highest IAA production to the extent of $35.6 \mu \mathrm{g} \mathrm{ml}^{-1}$ followed by $17.7 \mu \mathrm{g} \mathrm{ml}^{-1}$ by another strain LRE3. Endophytic strains ORE35 and CRE1 showed lowest IAA production (1.3 and $2.3 \mu \mathrm{g} \mathrm{ml}^{-1}$ respectively). The difference in IAA production by different endophytic isolates was statistically significant. The results of siderophore production by endophytes were scored on the basis of grading from +1 to +5 depending on the intensity of colour change of the medium from blue to fluorescent yellow. Maximum siderophore production activity was shown by strain LRE7, indicated by +5 , followed by strain PNE17 (+4) and strain LRE3 (+2) while strains CRE1, PRE8, WRE4 and ORE35 did not show any detectable siderophore production activity and thereby were scored as negative (Fig. 2b).

Endophytic isolates showed phosphate solubilization efficiency ranging from 0 to 103.6 on Pikovskaya's medium plates (Fig. 3a). Maximum efficiency was observed with strain CNE215 followed by strain LRE3 (50.8) and strain LRE7 (39.1). Wheat and oat root endophytes strain WRE4 and strain ORE27 did not show any detectable $P$ solubilization activity. Quantitatively measurement of $\mathrm{P}$ solubilization ranged from 69.1 to $562.9 \mu \mathrm{g} \mathrm{ml}^{-1}$ by different endophytes (Fig. 3b). The nodule endophytic strain CNE215 released maximum $\mathrm{P}$ in broth assay $\left(562.9 \mu \mathrm{g} \mathrm{ml}^{-1}\right)$ followed by LRE3 $(372.8 \mu \mathrm{g}$ $\mathrm{ml}^{-1}$ ) and LRE7 (268.2 $\left.\mu \mathrm{g} \mathrm{ml}^{-1}\right)$. WRE4 and ORE27 again showed lowest $\mathrm{P}$ solubilization activity (69.1 and $70.2 \mu \mathrm{g} \mathrm{ml}^{-1}$ respectively). The difference in $\mathrm{P}$ solubilization activity by different endophytic bacteria was statistically significant both qualitatively as well as quantitatively.

The zone of clearance by endophytic bacterial isolates on $\mathrm{CMC}$ agar plates indicated the amount of cellulase production and the zone diameter of clearance varied from 0 to $0.8 \mathrm{~cm}$. Only five strains i.e. LRE7, ORE27, LRE3, WRE4 and PNE17 showed the cellulose hydrolysis zone on CMC agar plates. In liquid Mandels and Sternberg medium, exoglucanase activity was measured as FPase activity was shown by five strains i.e. LRE7, ORE27, LRE3, WRE4 and PNE17 ranging from 0.026 to $0.11 \mathrm{IU} \mathrm{ml}^{-1}$. All of the isolates showed endoglucanase activity measured in the form of CMCase activity and ranged from 0.12 to $0.33 \mathrm{IU} \mathrm{ml}^{-1}$. The isolate LRE7 had highest FPase (0.11 IU ml $\mathrm{ml}^{-1}$ ) and CMCase (0.33 IU ml $\left.\mathrm{m}^{-1}\right)$ activity followed by ORE27 (0.1 and $0.31 \mathrm{IU} \mathrm{ml}^{-1}$ respectively) and other isolates showed very low or no activity (Fig. 4).

Antifungal activity of bacterial isolates in the form of zone of inhibition formed on PDA plates containing Fusarium oxysporum spores showed that majority of the endophytic bacteria did not show any inhibitory activity against Fusarium oxysporum, except two endophytic strains ORE27 and ORE35, which showed very low biocontrol activity.

In pot experiment different observations like nodule number, nodule fresh weight, root and shoot fresh weight, total shoot nitrogen, total shoot phosphorus and establishment of bacterial endophytes in chickpea roots as well as in nodules was determined after uprooting the plants at $60 \mathrm{~d}$ of growth. In case of wheat one absolute control was kept without any inoculation and root, shoot fresh weight, total shoot nitrogen and phosphorus and establishment of bacterial endophytes in roots was determined. Before uprooting, the growth of chickpea and wheat crops in pots is shown in Figure 5.

Establishment of different endophytic bacteria was assessed in chickpea and wheat roots after 15, 30 and 60d of growth by sterilizing 
the roots and streaking the crushed roots on their respective multiple antibiotic plates as used in earlier studies by Giri and Dudeja (2013a). In case of chickpea nodules, establishment was studied at $60 \mathrm{~d}$ of plant growth. At 15 and 30d of inoculation, none of the isolate was able to enter the chickpea or wheat roots, while at $60 \mathrm{~d}$ of growth three strains CNE215, PNE17 and ORE27 were detected in the chickpea roots and maximum number $2.05 \operatorname{logs} \mathrm{CFU}$ plant $\operatorname{root}^{-1}$ of strain PNE17 was observed (Table 1). In wheat roots at $60 \mathrm{~d}$ of growth another three strains LRE3, LRE7 and ORE27 were detected (Table 2). Strain LRE3 recorded maximum number of $2.17 \log$ CFU plant root $^{-1}$.

Increased nodulation in chickpea after mesorhizobial inoculation to 39 nodules plant $^{-1}$ as compared 19 nodules per plant without inoculation with native mesorhizobial were observed (Table 1). Nodulation ranged from 54 to 76 nodules plant $^{-1}$, after co inoculation with endophytes. Similar trend in chickpea nodule fresh weight was observed. Highest nodulation was observed in chickpea after co inoculation with B. subtilis, strain ORE27. Statistically significant increase in chickpea roots and shoot fresh biomass after co inoculation with endophytes was observed. Highest root and shoot fresh weight was observed in chickpea inoculated with strains WRE20 and ORE27 respectively. Wheat root and shoot fresh weight after co inoculation ranged from 2.08 to 2.99 g plant $^{-1}$ and 2.00 to $2.25 \mathrm{~g} \mathrm{plant}^{-1}$ as compared to uninoculated control 1.15 and $1.30 \mathrm{~g}$ plant $^{-1}$ respectively (Table 2). Highest root and shoot fresh weight was observed in wheat inoculated with strain PNE17.

Table.1 Establishment and functionality of endophytic bacterial inoculation in chickpea grown under pot culture conditions

\begin{tabular}{|c|c|c|c|c|c|c|c|c|c|}
\hline \multirow{3}{*}{$\begin{array}{c}\text { Bacterial } \\
\text { endophytic strains }\end{array}$} & \multirow{2}{*}{\multicolumn{2}{|c|}{$\begin{array}{l}\text { Root endophytes } \\
\text { log CFU } \\
\text { (per plant roots) }\end{array}$}} & \multirow{3}{*}{$\begin{array}{c}\text { Nodule } \\
\text { endophytes } \\
\text { log CFU } \\
\text { (per plant) } \\
60 \text { d }\end{array}$} & \multicolumn{4}{|c|}{ 60d } & \multirow{3}{*}{$\begin{array}{c}\text { Nitrogen } \\
\text { uptake in } \\
\text { shoot } \\
\left(\mathrm{mg}^{-1}\right) \\
\left.\text { plant }^{-1}\right)\end{array}$} & \multirow{3}{*}{$\begin{array}{l}\text { Phosphorus } \\
\text { uptake in } \\
\text { shoot } \\
\left.\text { (mg plant }^{-1}\right)\end{array}$} \\
\hline & & & & \multirow{2}{*}{$\begin{array}{c}\text { Nodule } \\
\text { no. }\end{array}$} & \multicolumn{3}{|c|}{ Fresh weight $\left(\mathrm{g} \mathrm{plant}^{-1}\right)$} & & \\
\hline & 15 and 30d & $60 \mathrm{~d}$ & & & Nodules & Roots & Shoots & & \\
\hline Uninoculated & - & - & - & 19 & 0.29 & 2.25 & 2.30 & 1.98 & 0.89 \\
\hline Meso* & - & - & - & 39 & 0.42 & 4.10 & 4.34 & 3.87 & 1.68 \\
\hline Meso + CNE1 & - & - & - & 67 & 1.02 & 5.53 & 5.20 & 4.41 & 1.92 \\
\hline Meso + CNE215 & - & 1.98 & - & 71 & 0.98 & 6.11 & 5.19 & 9.67 & 3.56 \\
\hline Meso + PRE8 & - & - & - & 72 & 1.22 & 6.17 & 5.59 & 5.35 & 2.09 \\
\hline Mseo + PNE17 & - & 2.05 & - & 60 & 0.81 & 5.99 & 5.95 & 9.09 & 2.99 \\
\hline Meso + PNE92 & - & - & - & 61 & 0.82 & 5.98 & 5.19 & 9.45 & 2.95 \\
\hline Meso + LRE3 & - & - & - & 54 & 1.01 & 5.88 & 5.05 & 7.66 & 2.78 \\
\hline Meso + LRE7 & - & - & - & 56 & 0.92 & 5.96 & 5.11 & 8.89 & 2.88 \\
\hline Meso + WRE4 & - & - & - & 73 & 1.30 & 5.09 & 5.28 & 5.01 & 2.78 \\
\hline Meso + WRE20 & - & - & - & 70 & 1.09 & 6.22 & 5.40 & 6.03 & 2.54 \\
\hline Meso + ORE27 & - & 1.25 & - & 76 & 1.02 & 5.92 & 6.12 & 6.20 & 2.13 \\
\hline Meso +ORE35 & - & - & - & 69 & 1.09 & 6.08 & 5.11 & 7.89 & 2.15 \\
\hline SE(m) & - & 0.04 & - & 3.56 & 0.05 & 0.21 & 0.14 & 0.25 & 0.42 \\
\hline CD at $5 \%$ & - & 0.11 & - & 10.33 & 0.17 & 0.62 & 0.41 & 0.74 & 1.22 \\
\hline
\end{tabular}

Meso $^{*}=$ Mesorhizobium sp. Strain CH1233 
Table.2 Establishment and functionality of endophytes in wheat grown in pots

\begin{tabular}{|c|c|c|c|c|c|c|}
\hline \multirow[t]{2}{*}{$\begin{array}{c}\text { Bacterial } \\
\text { endophytes }\end{array}$} & \multicolumn{2}{|c|}{$\begin{array}{c}\text { Root endophytes } \\
\text { log CFU } \\
\text { (per plant root) }\end{array}$} & \multicolumn{2}{|c|}{$\begin{array}{c}\text { Fresh weight } \\
\text { 60d } \\
\text { g plant }^{-1} \\
\end{array}$} & \multirow[t]{2}{*}{$\begin{array}{c}\text { Nitrogen } \\
\text { uptake in shoot } \\
\left(\mathrm{mg} \mathrm{Plant}^{-1}\right)\end{array}$} & \multirow{2}{*}{$\begin{array}{l}\text { Phosphorus } \\
\text { uptake in } \\
\text { shoot } \\
\left(\text { mg Plant }^{-1}\right)\end{array}$} \\
\hline & 15 and $30 d$ & 60d & Roots & Shoots & & \\
\hline Control & - & - & 1.15 & 1.30 & 1.18 & 0.96 \\
\hline CNE1 & - & - & 2.53 & 2.00 & 3.42 & 1.89 \\
\hline CNE215 & - & - & 2.11 & 2.19 & 5.02 & 2.91 \\
\hline PRE8 & - & - & 2.17 & 2.09 & 4.23 & 1.88 \\
\hline PNE17 & - & - & 2.99 & 2.25 & 6.62 & 2.98 \\
\hline PNE92 & - & - & 2.98 & 2.19 & 5.98 & 1.95 \\
\hline LRE3 & - & 2.17 & 2.88 & 2.05 & 4.76 & 2.13 \\
\hline LRE7 & - & 2.08 & 2.96 & 2.11 & 5.68 & 2.67 \\
\hline WRE4A & - & - & 2.09 & 2.18 & 4.57 & 1.78 \\
\hline WRE20 & - & - & 2.22 & 2.00 & 5.02 & 2.14 \\
\hline ORE27 & - & 1.98 & 2.92 & 2.32 & 7.22 & 3.01 \\
\hline ORE35 & - & - & 2.08 & 2.31 & 5.93 & 2.06 \\
\hline SE(m) & - & 0.10 & 0.14 & 0.17 & 0.10 & 0.08 \\
\hline CD at $5 \%$ & - & 0.31 & 0.42 & 0.51 & 0.30 & 0.23 \\
\hline
\end{tabular}

Fig.1 Blast algorithm tree using fast minimum evolution based on alignment of 16S rRNA gene sequences, showing the relationships of endophytes with other related species of Bacillus. Distance 0.1 between sequence used for tree generation predicts expected fraction of base substitutions per site given the fraction of mismatched bases in the aligned region

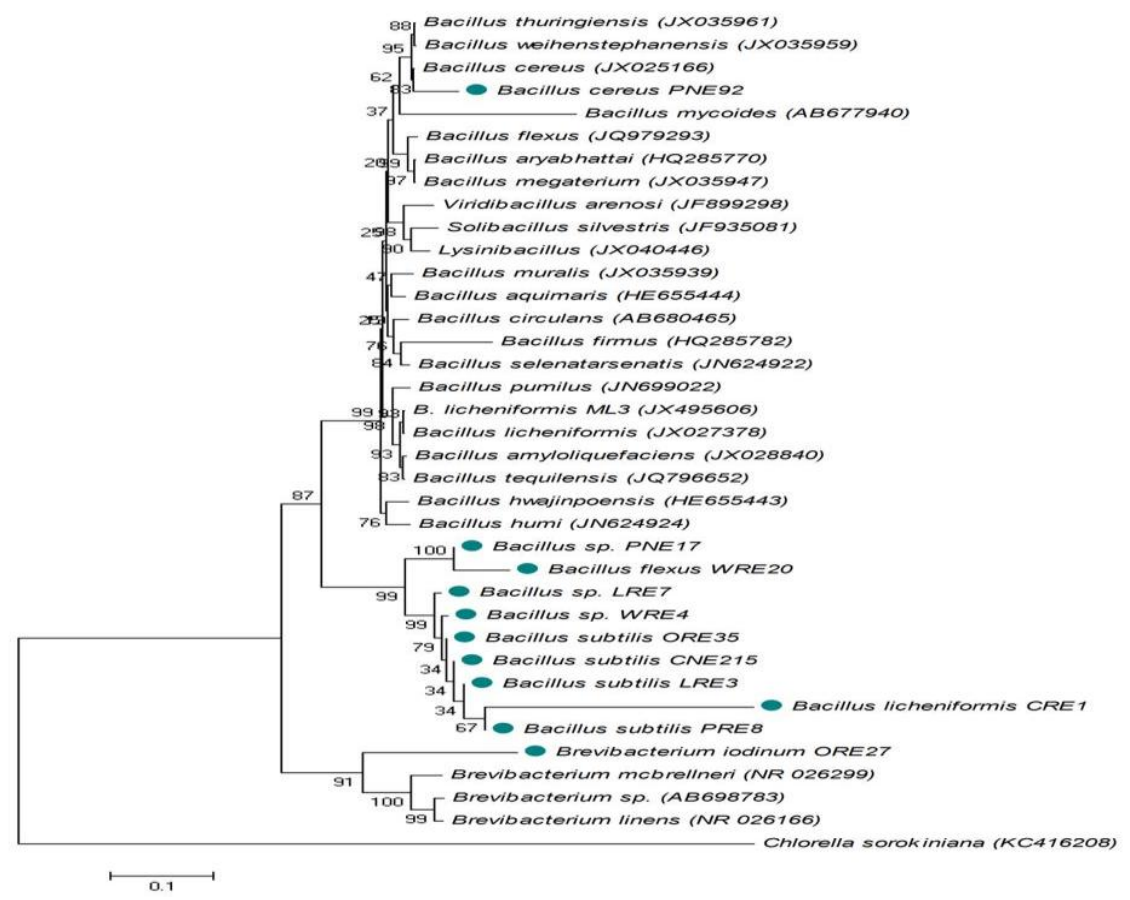


Fig.2 Screening of bacterial endophytes for PGP traits - IAA production (a) and siderophore production (b)
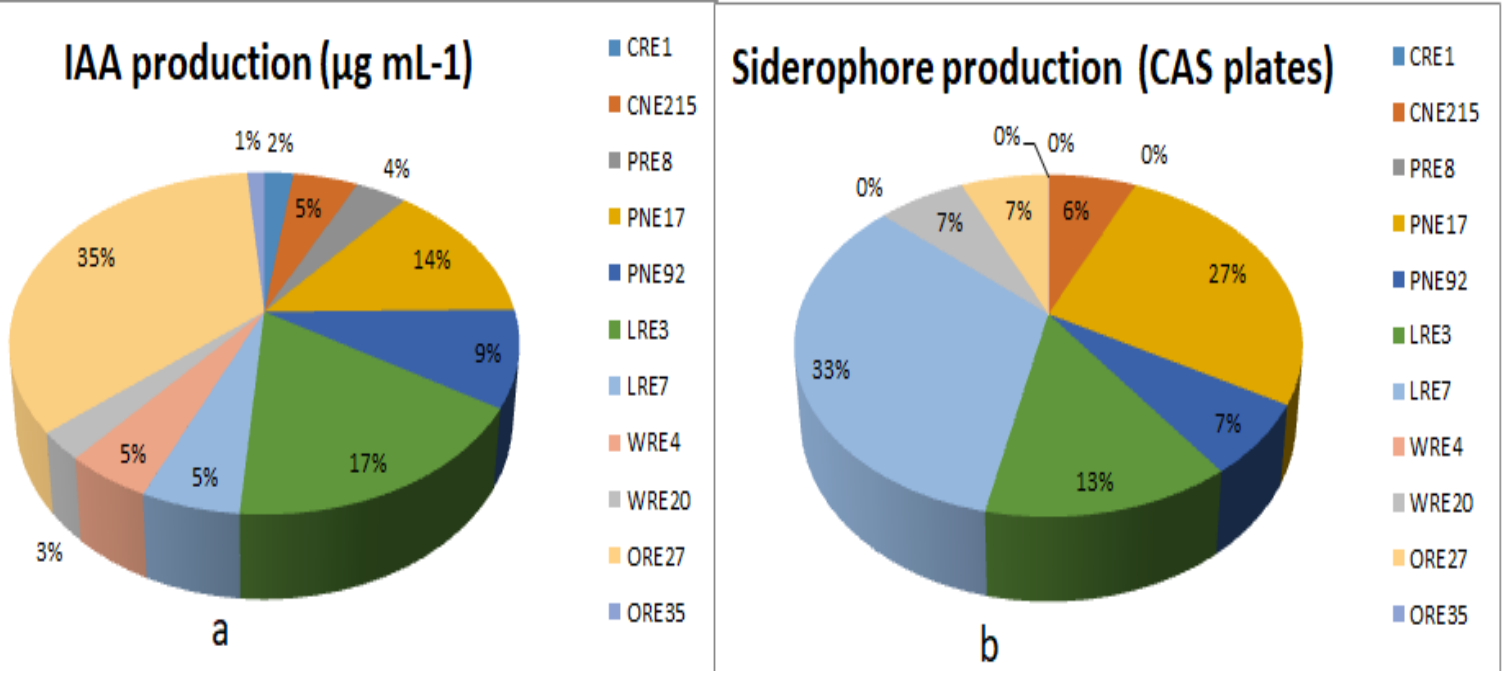

Fig.3 Screening of bacterial endophytes for PGP traits - P solubilization efficiency measured on Pikovskaya's plates $=\mathrm{HD} / \mathrm{CD} \times$ Annule area $\times 100$ (a) and siderophore production and $\mathrm{P}$ solubilization in broth culture (b)

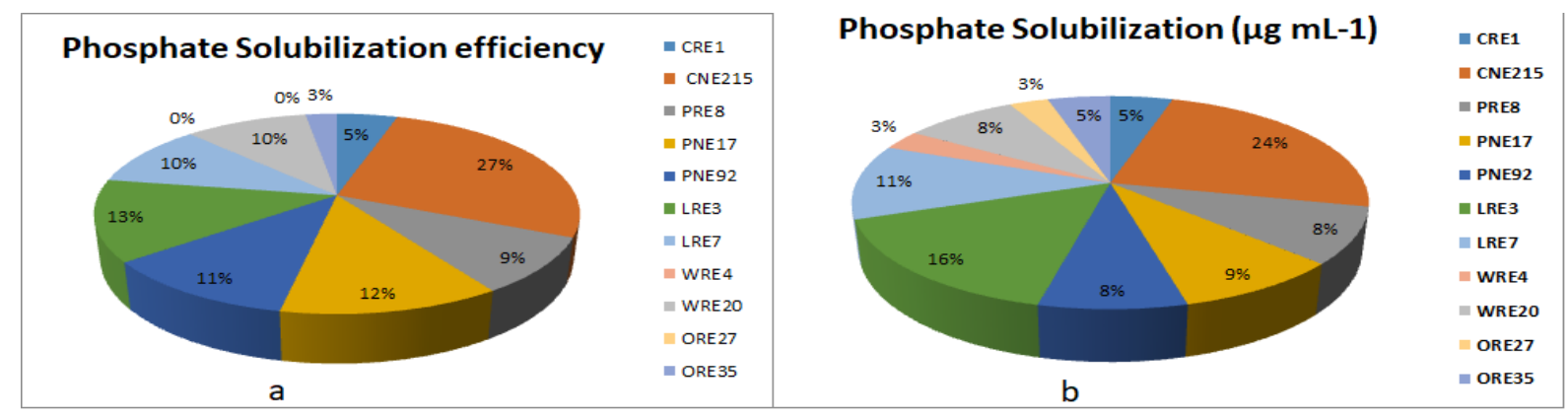

Fig.4 Screening of bacterial endophytes for traits like cellulose, exoglucanase and endogluconase production for establishment as endophyte in host microbiome

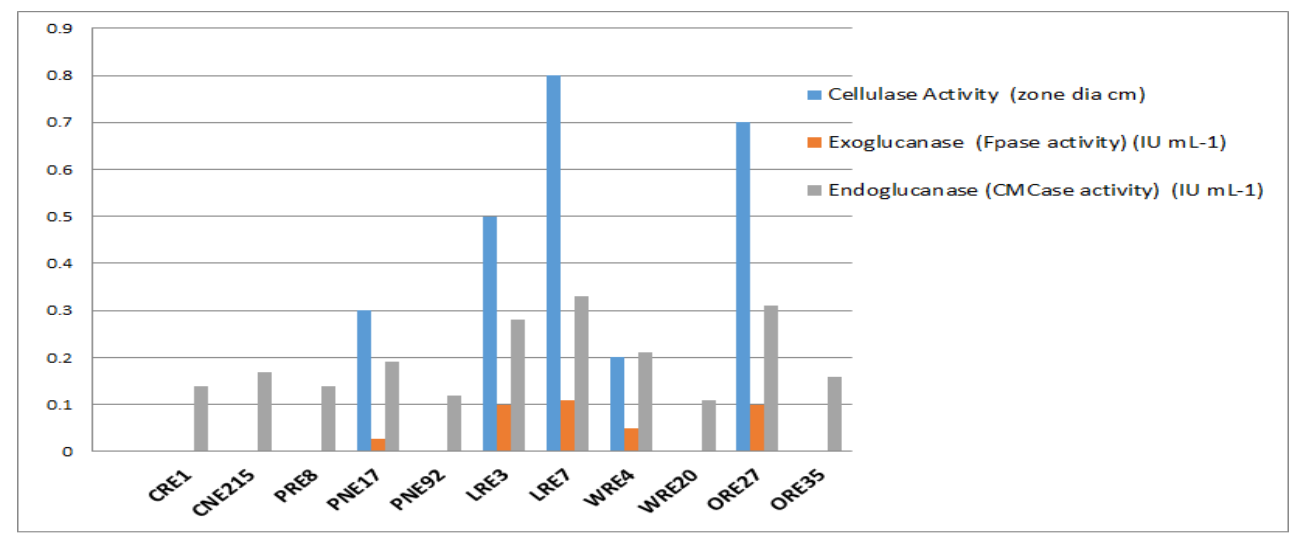


Fig.5 Functionality of bacterial endophytes in Chickpea (a) and wheat (b) microbiome in after inoculation with different bacterial endophytes

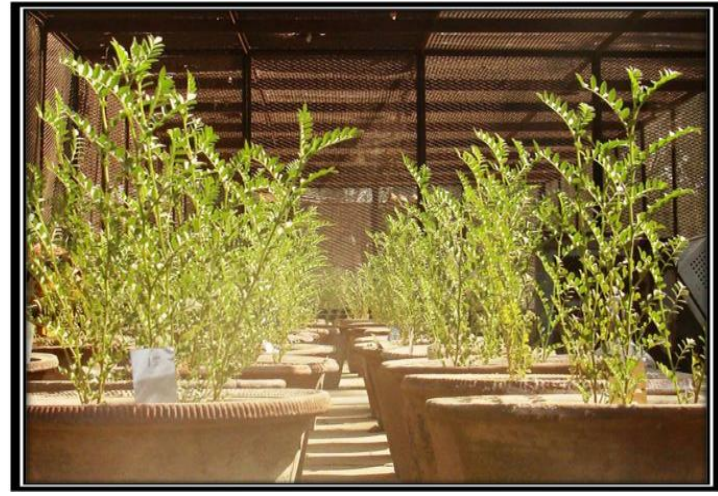

Fig.5a

Chickpea total shoot nitrogen contents increased from 1.98 to $3.87 \mathrm{mg}$ plant $^{-1}$ after mesorhizobial inoculation and further increased to $9.67 \mathrm{mg} \mathrm{plant}^{-1}$ after inoculation with strain CNE215 and was statistically significant (Table 1). Wheat inoculation with different endophytic bacterial strains also showed a statistically significant increase in total shoot nitrogen contents and particularly with strain ORE27 (Table 2). Total shoot P contents of chickpea and wheat also increased after co inoculation with different endophytic bacteria. Statistically significant and highest total shoot $\mathrm{P}$ contents in chickpea inoculated with strain CNE215 and in wheat with strain ORE27 were observed.

An endophytic bacterial association with plants and extent of beneficial effects incurred by plants depends upon large number factors. Still it is controversial whether some level of host specificity exists or not. A total of 11 endophytic bacterial strains isolated from different hosts and tissues were used to assess the level of host specificity. Initially, the beneficial properties exhibited by these endophytic bacteria were assessed as these enhance plant growth. All the 11 bacterial strains (CRE1, CNE215, PRE8, PNE17, PNE92, LRE3, LRE7, WRE4, WRE20, ORE27, and ORE35) produced varying

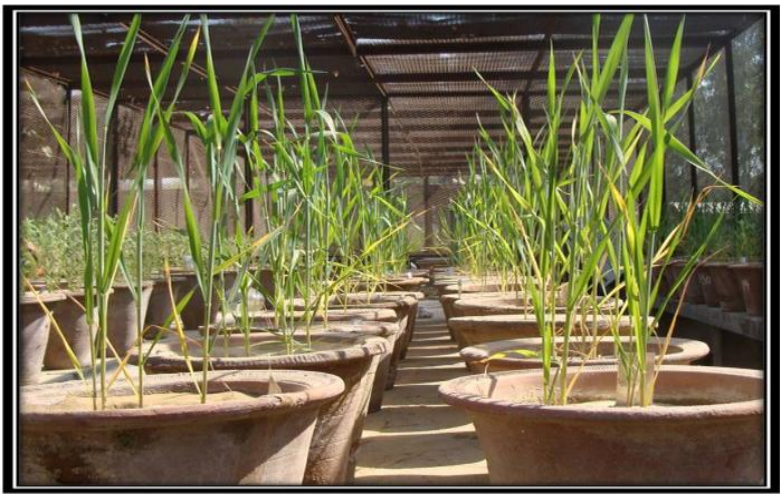

Fig.5b

quantities of IAA. Isolates made from different tissues and hosts have been reported to produce IAA (Hung and Annapurna 2004; Li et al., 2008; Selvakumar et al., 2008; Dudeja 2016, Abedinzadeh et al., 2018; Brígido et al., 2019). Root growth promotion studies conducted in this lab showed that majority of isolates promoted the growth of chickpea and field pea roots in root growth promotion assay in agar plates (Saini et al., 2015a, Narula et al., 2013a). Only very low number of endophytes among large number of bacterial isolates from peanut and Sophora alopecuroides, were able to produce auxin (Taurian et al., 2010; Zhao et al., 2011). All strains solubilized $\mathrm{P}$ and solubilization efficiency ranged from 69.1 to $562.9 \mu \mathrm{g} \mathrm{mL}^{-1}$. Elsewhere majority of endophytic isolates from different hosts has been reported to solubilize P (Li et al., 2008; Selvakumar et al., 2008; Forchetti et al., 2007; Lopez et al., 2011; Narula et al., 2013a; Saini et al., 2015b; Abedinzadeh et al 2018; Brígido et $a l ., 2019)$, though none of endophytic isolates from roots of Prosopis strombulifera solubilized P (Sgroy et al., 2009).

Siderophore producing activity, has been reported in majority of the endophytes (Matsuoka et al., 2013; Catherine et al., 2012; Gangwar and Kaur, 2009; Abedinzadeh et al., 
2018; Brígido et al., 2019), but in the present study only few isolates produced siderophores. Similarly cellulase and FPase activity was not observed in strains CRE1, CNE215, PRE8, PNE92, WRE20 and ORE35. Bio control of phyto-pathogens by endophytic bacteria is also an important trait for improved plant health and large numbers of endophytic microbes have been reported to act as bio control agents against Fusarium or other pathogens (Ma et al., 2013) but in the present study only two strains inhibited $F$. oxysporum growth and that too to lesser extent. One very interesting observation made in the study was that if one beneficial activity was low, than other was high indicating an overall growth promoting activity. In few strains multiple growth promoting activities were present. Further these activities could not be correlated with the establishment in the roots or nodules. It seems that endophytes enter a plant tissue through natural cracks at the region where the lateral roots and with age more cracks appear in roots through which endophytes enter the roots. This mode of entry is often combined with active penetration, if cell wall degrading enzymes are present.

Endophytes are also known to enhance plant growth promotion in all the crops including legumes and non-legumes and $\mathrm{N}_{2}$ fixation is also enhanced in legumes when used as inoculants. (Narula et al., 2013a; Saini et al., 2015a; Kumar et al., 2013). All the endophytic bacterial isolates were inoculated together with Mesorhizobium in chickpea and alone in wheat showed enhanced plant growth. The strains from field pea and wheat roots were not better plant growth promoters as compared to strains from chickpea, lucerne and oat roots. Again host specificity does not seem to be there, but isolates made from nodules were comparatively better as compared to isolates from roots. There was no significant correlation between plant growth promotion and in the results of phenotypic traits. Furthermore, other mechanisms that were not investigated in this study may also be involved in the response of increased growth of plants (Compant et al., 2010). Elsewhere Dias et al., (2013), reported that endophytic isolates differed significantly in the production of IAA and also in the solubilization of $\mathrm{P}$, but there was no clear relationship between the amounts of IAA and $P$ solubilization to their contribution to plant growth promotion. Bacterization experiments in different crops showed that bacterial endophytes promoted growth more often (Sturz et al., 1997; Shi et al., 2009; Muthukumar et al., 2010; Li et al., 2010; Narula et al., 2013a; Saini et al., 2015a).

Endophytic bacteria are found in each and every plant known and in all the tissues of plants. Different types of bacteria, either tissue specific or nonspecific has been isolated from plants. In spite of these differences these endophytes may perform similar or different function in all the tissue of plants. To have better understanding of the bacterial root endophytes molecular diversity of the isolates from all the crops was assessed in the present investigation. DNA of the selected 11 bacterial endophytes was extracted and 16S rDNA was amplified followed by purification and sequencing of the 16S rDNA partial sequence.

Most of the endophytes showed more than 98\% similarity with Firmicutes, except one i.e. ORE27 which belonged to Actinobacteria i.e. Brevibacterium iodinum. This indicated that most of the isolates belonged to Bacillus genera though species were different. Other workers apart from diversity studies have also identified the endophytes from different crops and most common bacterial genera in roots are usually Bacillus, Pseudomonas and Micrococcus. 
It seems that there is no host specificity in the entry of different endophytic isolates in different host and non-host roots and it was independent of the source from which these were isolated. Environmental and ecological conditions are determining the prevalence of different genera and their entry into roots or nodules. Whether the endophytes were entering in plant roots or remaining outside as rhizospheric are benefiting the plants by enhanced root and shoot growth as well as $\mathrm{N}$ and $\mathrm{P}$ uptake in shoots. Bacilli which are spore formers are the better candidate to survive under adverse conditions particularly prevalent in Northern India i.e. temperature up to $48^{\circ} \mathrm{C}$ during the summer season. Further presence of multiple beneficial traits; make these isolates the most potent candidate for enhancing crop productivity.

\section{References}

Abedinzadeh, M., Etesami, H., Alikhani, H.A. (2018). Characterization of rhizosphere and endophytic bacteria from roots of maize (Zea mays L.) plant irrigated with wastewater with biotechnological potential in agriculture Biotechnology Reports 20: 1-12 doi.org/10.1016/j.btre. e00305.

Ali, S., Charles, T.C., Glick, B.R. (2014a). Amelioration of high salinity stress damage by plant growth-promoting bacterial endophytes that contain ACC deaminase. Plant Physiol. Biochem. 80: 160-167.

Ali, S., Charles, T.C., Glick, B.R. (2012). Delay of flower senescence by bacterial endophytes expressing 1-amino cyclopropane-1-carboxylate deaminase. J. Appl. Microbiol. 2012. 113, 11391144.

Ali, S., Duan, J., Charles, T.C., Glick, B.R. (2014b). A bioinformatics approach to the determination of genes involved in endophytic behavior in Burkholderia spp. J. Theor. Biol. 343: 193-198.

Altschul, S.F., Gish, W., Miller, W., Myers,
E.W., Lipman, D.J. (1990). Basic local alignment search tool. J. Mol. Biol. 215: $403-410$

Ausubel, F.M., Brent, R., Kingston, R.E., Moore, D.D. et al. (Eds.) (2001). Current Protocols in Molecular Biology, Vol. 1, Unit 2.4. John Wiley, New York.

Berendsen, R.L., Pieterse, C.M.J., Bakker, P.A.H.M. (2012). The rhizosphere microbiome and plant health, Trend. Plant Sci. 17: 478-486.

Bremmer, J.M. (1960). Total nitrogen. In: Methods of soil Analysis. (ed. C.A. black), American Society of Agronomy, Madison. 2: 1149 - 1178 .

Brígido, C., Singh, Sakshi, Menéndez, E., Tavares, M.J., Glick, B.R., Félix, M.R., Oliveira, S., Carvalho, M. (2019). Diversity and Functionality of Culturable Endophytic Bacterial Communities in Chickpea Plants. Plants. 8:42; doi:10.3390/plants80200 42.

Catherine, N/N., Viviene, N.M., Akio, T., Catherine, W.M. (2012). Isolation and identification of endophytic bacteria of bananas (Musa sp.) in Kenya and their potential as biofertilizers for sustainable banana production. African $J$. Microbiol. Res. 6(34): 6414 - 6422.

Compant, S., Reiter, B., Sessitsch, A., Nowak, J., Clement, C., Barka, E.A.(2005). Endophytic colonization of Vitis vinifera L. by plant growth promoting bacterium Burkholderia sp strain PsJN. Appl. Environ. Microbiol. 71: 16851693.

Coutinho, B.G., Licastro, D., Mendonc Previato, L., Cámara, M., Venturi, V. (2015). Plant-influenced gene expression in the rice endophyte Burkholderia kururiensis M130. Molec. Plant-Microbe Interact. 28: 10-21.

Dias, A., Santos, S.G., Vasconcelos, V.G., Radl, V., Xavier, G.R. (2013). Screening of plant growth promoting rhizobacteria for the development of vegetable crops inoculants. African $J$ Microbiol Res. 7(19): 2087 - 2092, 
Dudeja, S.S., Giri, R., Saini, R., Suneja-Madan, P, Kothe, E. (2012). Interaction of endophytic microbes with legumes. $J$ Basic Microbiol. 52: 248 - 260.

Dudeja, S.S., Giri, R. (2014). Beneficial properties, colonization, establishment and molecular diversity of endophytic bacteria (review) African J Microbiol Res. 8(15):1562 - 1572

Dudeja, S.S. (2016). Beneficial Effects and Molecular Diversity of Endophytic Bacteria in Legume and Non legumes. In: Singh DP et al. (eds) Microbial Inoculants in Sustainable Agricultural Productivity. pp 245-256

Etesami, H., Maheshwari, D.K. (2018). Use of plant growth promoting rhizobacteria (PGPRs) with multiple plant growth promoting traits in stress agriculture: action mechanisms and future prospects, Ecotoxicol. Environ. Saf. 156: 225-246.

Forchetti, G., Masciarelli, O., Alemano, S., Alvarez, D., Abdala, G. (2007). Endophytic bacteria in sunflower (Helianthus annuus L.): isolation, characterization, and production of jasmonates and abscisic acid in culture medium. Appl Microbiol Biotechnol. 76: 1145 - 1152 .

Gamalero, E., Glick, B.R. (2011). Mechanisms used by plant growth-promoting bacteria. In: Maheshwari, M.K. (Ed.), Bacteria in Agrobiology: Plant Nutrient Management. Springer-Verlag, Berlin Heidelberg, pp. 17-46.

Gangwar, M., Kaur, G. (2009). Isolation and characterization of endophytic bacteria from endorhizosphere of sugarcane and ryegrass. Internet J Microbiol. 7(1): 35 42.

Giri, R., Dudeja, S.S.(2013a). Host specificity of plant endophytic bacterial interactions: Root and nodule colonization under sterilized sand conditions in disposable coffee cups. Central European J Exptl Biol. 2 (4): 22 $-26$

Giri, R., Dudeja, S.S. (2013b). Root colonization of root and nodule endophytic bacteria in legume and non legume plants grown in liquid medium. J Microbiol Res. 1(6): 75 - 82

Glick, B.R. (2012). Plant growth-promoting bacteria: mechanisms and applications. Scientifica Article ID 963401.

Glickmann, E., Dessaux, Y. (1995). A critical examination of the specificity of the Salkowski reagent for indole compounds produced by phytopathogenic bacteria. Appl Environ Microbiol. 61: 793 - 796.

Hartman, A., Singh, M., Klingmuler, W. (1983). Isolation and characterization of Azospirillum mutants excreting high amounts of indole acetic acid. Can J Microbiol. 29: 916 - 923.

Hung, P.Q., Annapurna, K. (2004). Isolation and characterization of endophytic bacteria in soybean (Glycine sp.). Omon rice 12: 92-101.

Jackson, M.L. (1993). Soil Chemical Analysis. 1st Edn., Prentice Hall of India Pvt. Ltd., New Delhi, India.

Jangu, O.P., Sindhu, S.S. (2011). Differential response of inoculation with indole acetic acid producing Pseudomonas sp. in green gram (Vigna radiate L.) and black gram (Vigna mungo L.). Microbiol J. 1: 159 - 173.

Jha, P.N., Gupta, G., Jha, P., Mehrotra, R. (2013). Association of Rhizospheric/ Endophytic Bacteria with Plants: A Potential Gateway to Sustainable Agriculture. Greener J Agricul Sci. 3 (2):73 - 84.

John, M.K. (1970). Calorimetric determination of phosphorus in soil and plant material with ascorbic acid. J Soil Sci. 109: 214220.

Kirchhof, G., Reis, V.M., Baldani, J.I., Eckert, B., Döbereiner, J., Hartmann, A. (1997). Occurrence, physiological and molecular analysis of endophytic diazotrophic bacteria in gram.ineous energy plants. Plant Soil 194: 45-55.

Kumar, V., Pathak, D.V., Dudeja, S.S., Saini, R., Narula, S, Anand, R.C. (2013). Legume nodule endophytes more 
diverse than endophytes from roots of legumes or non legumes in soils of Haryana, India. J Microbiol Biotechnol Res. 3 (3): 83 - 92

KLacava, P.T. and Azevedo, J.L. (2013). Endophytic bacteria: a biotechnological potential in agrobiology system. In: Maheshwari, D.K., Saraf, M., Aeron, A. (Eds.), Bacteria in Agrobiology: Crop Productivity. Springer-Verlag, Berlin, Heidelberg, pp.1-44.

Li, J.H., Wang, E.T., Chen, W.F., Chen, W.X. (2008). Genetic diversity and potential for promotion of plant growth detected in nodule endophytic bacteria of soybean grown in Heilongjiang province of China. Soil Biol Biochem. 40: 238-246.

Li, Y.H., Zhu, J.N., Zhai, Z.H., Zhang, Q. (2010). Endophytic bacterial diversity in roots of Phragmites australis in constructed Beijing Cuihu Wetland (China). FEMS Microbiol Lett. 309(1): 84-93.

Lopez, B.R., Bashan, Y., Bacilio, M. (2011). Endophytic bacteria of Mammillaria fraileana, an endemic rock-colonizing cactus of the Southern Sonoran Desert. Arch Microbiol.193: 527-541.

Ma, L., Cao, Y.H., Cheng, M.H., Huang, Y., Mo, M.H., Wang, Y., Yang, J.Z., Yang, F.X. (2013). Phylogenetic diversity of bacterial endophytes of Panax notoginseng with antagonistic characteristics towards pathogens of root-rot disease complex. Antonie Van Leeuwenhoek 103(2): 299-312.

Mandels, M., Sternberg, D. (1976). Recent advances in cellulase technology. $J$ Ferment Technol.54: 267.

Matsuoka, H., Akiyama, M., Kobayashi, K., Yamaji, K. (2013). Fe and P solubilization under limiting conditions by bacteria isolated from Carex kobomugi roots at the Hasaki coast. Curr Microbiol. 66(3): 314-321

Muthukumar, A., Bhaskaran, R., Kumar, S.K. (2010). Efficacy of endophytic Pseudomonas fluorescens (Trevisan) migula against chilli damping-off. $J$ Biopest. 3: 105-109.

Narula, S., Anand, R.C., Dudeja, S.S., Kumar, V., Pathak, D.V. (2013b). Molecular diversity of root and nodule endophytic bacteria from field pea (Pisum sativum L.). Legume Research 36(4): 344-350

Narula ,S., Anand, R.C., Dudeja, S.S. (2013a). Beneficial traits of endophytic bacteria from field pea nodules and plant growth promotion of field pea. J. Food Legume 26(3-4):73-79

Reinhold-Hurek, B. and Hurek, T. (2011). Living inside plants: bacterial endophytes. Curr Opin Plant Biol. 14: 435-443.

Ryan, R.P., Germaine, K., Franks, A., Ryan, D.J. (2008). Dowling, D.N. Bacterial endophytes: recent developments and applications. FEMS Microbiol. Lett. 278: 1-9.

Saini, R., Dudeja, S.S., Giri, R., Kumar, V. (2015b). Isolation, characterization and evaluation of bacterial root and nodule endophytes from chickpea cultivated in Northern India J Basic Microbiol.55:7481

Saini, R., Kumar, V., Dudeja, S.S., Pathak, D.V. (2015a). Beneficial effects of inoculation of endophytic bacterial isolates from roots and nodules in chickpea. Int J Curr Microbiol App Sci. 4(10): 207-221

Saitou, N., Nei, T. (1987). The neighbor-joining method: a new method for reconstructing phylogenetic trees. Mol Biol Evol. 4(4): 406-425.

Sambrook, J., Russell, D.W. (2001). Molecular Cloning: A Laboratory Manual, Vol. 1, Cold Spring Harbor, New York.

Santoyoa, G., Moreno-Hagelsiebb, G., OrozcoMosquedac, M.C., Glick, B.R. (2016). Plant growth-promoting bacterial endophytes Microbiol. Res. 183: 92-99.

Schwyn, B. and Neilands, J.B. (1987). Universal chemical assay for the detection and determination of siderophores. Anal Biochem. 160: 4756. 
Selvakumar, G., Kundu, S., Gupta, A.D., Shouche, Y.S., Gupta, H.S. (2008). Isolation and characterization of non rhizobial plant growth promoting bacteria from nodules of Kudzu (Pueraria thunbergiana) and their effect on wheat seedling growth. Curr Microbiol. 56: 134-139.

Sgroy, V., Cassán, F., Masciarelli, O., Papa, M.F. et al., (2009). Isolation and characterization of endophytic plant growth promoting (PGPB) or stress homeostasis-regulating (PSHB) bacteria associated to the halophyte Prosopis strombulifera. Appl. Microbiol. Biotechnol. 85(2): 371-381.

Shi, Y., Lou, K., Li, C. (2009). Promotion of plant growth by phytohormoneproducing endophytic microbes of sugar beet. Biol Fertil Soils 45: 645 - 653.

Sindhu, S.S., Gupta, S.K., Dadarwal, K.R. (1999). Antagonistic effect of Pseudomonas spp. on pathogenic fungi and enhancement of growth of green gram (Vigna radiata). Biol Fertil Soils 29: 62-68.

Stoltzfus, J.R., So, R., Malarvithi, P.P., Ladha, J.K., De Bruijn, F.J. (1997). Isolation of endophytic bacteria from rice and assessment of their potential for supplying rice with biologically fixed nitrogen. Plant Soil 194: 25-36.

Sturz, A.V., Christie, B.R., Matheson, B.G., Nowak, J. (1997). Biodiversity of endophytic bacteria which colonize red clover nodules, roots, stems and foliage and their influence on host growth. Biol Fertil Soils 25: $13-19$.

Tamura, K., Dudley, J., Nei, M., Kumar, S. (2007). MEGA4: Molecular Evolutionary Genetics Analysis (MEGA) software version 4.0. $\mathrm{Mol}$ Biol Evol. 24: 1596-1599.

Taurian, T., Anzuay, M.S., Angelini, J.G., Tonelli, M.L., Ludueña, L., Pena, D., Ibáñez, F., Fabra, A. (2010). Phosphatesolubilizing peanut associated bacteria: screening for plant growth promoting activities. Plant Soil 329: 421-431.

Tshikhudo, P. P., Ntushelo, K., Mudau, F. N., Salehi, B., Sharifi-Rad, M., Martins, N., Martorell, M., Sharifi-Rad, J. (2019). Understanding Camellia sinensis using Omics Technologies along with Endophytic Bacteria and Environmental Roles on Metabolism: Appl. Sci. 9: 281; doi:10.3390/app9020281

Wadhwa, K., Dudeja, S.S., Yadav, R.K. (2011). Molecular diversity of native field pea rhizobia trapped by five contrasting field pea genotypes in Indian soils. $J$. Basic Microbiol. 51: 89-97.

Zhao, L., Xu, Y., Sun, R., Deng, Z., Yang, W., Wei, G. (2011). Identification and characterization of the endophytic plant growth prompter Bacillus cereus strain MQ23 isolated from Sophora alopecuroides root nodules. Braz. J. Microbiol. 42: 567 - 575

\section{How to cite this article:}

Rupa Giri and Surjit Singh Dudeja. 2019. Establishment and Functionality of Diverse Endophytic Bacteria from Different Hosts in Chickpea and Wheat Microbiome. Int.J.Curr.Microbiol.App.Sci. 8(04): 2273-2286. doi: https://doi.org/10.20546/ijcmas.2019.804.266 